\title{
Synthesis of new coumarin derivatives with suspected anticoagulant activity
}

\author{
Yasser Fakri Mustafa \\ Department of Pharmaceutical Sciences, College of Pharmacy, \\ University of Mosul, Mosul
}

$\underline{\text { Received }}$

23.2.2012
Accepted

30.4 .2012

\section{ABSTRACT}

Objectives: To synthesize three series of new coumarin derivatives and to screen their anticoagulant activity in rabbits in order to define in more exact terms the structural features that responsible for the anticoagulant activity of coumarins.

Methods: the first series was synthesized by esterification the 7-hydroxycoumarin with benzoic acid, salicylic acid and 5-amino salicylic acid to give derivatives I-III; the second series was synthesized by the formation of amide linkage between 6aminocoumarin and benzoic acid, salicylic acid and 5-amino salicylic acid to give derivatives IV-VI while the third series was synthesized by esterification the coumarin-6-carboxylic acid with phenol, resorcinol and $m$-chlorophenol to give derivatives VII-IX.

The anticoagulant activity of these derivatives (I-IX) was investigated in rabbits via Quick's one-stage method; the initial effect of each derivative on the prothrombine time for five rabbits before and after oral administration was measured.

Results: The chemical structure of these derivatives was characterized by physical and spectroscopic techniques as FTIR, UV and ${ }^{13} \mathrm{C}-\mathrm{NMR}$ spectra. Depending on prothrombin time measurements, derivatives II and VIII showed a significant anticoagulant activity through increasing the prothrombine time while the other derivatives showed an insignificant anticoagulant activity.

Conclusion: This study proposed that the coumarin derivatives contained an ester linkage at position 6 or 7 separated from a hydroxyl group by short carbon side chain may show anticoagulant activity.

Key words: Synthesis, coumarin, prothrombine time.

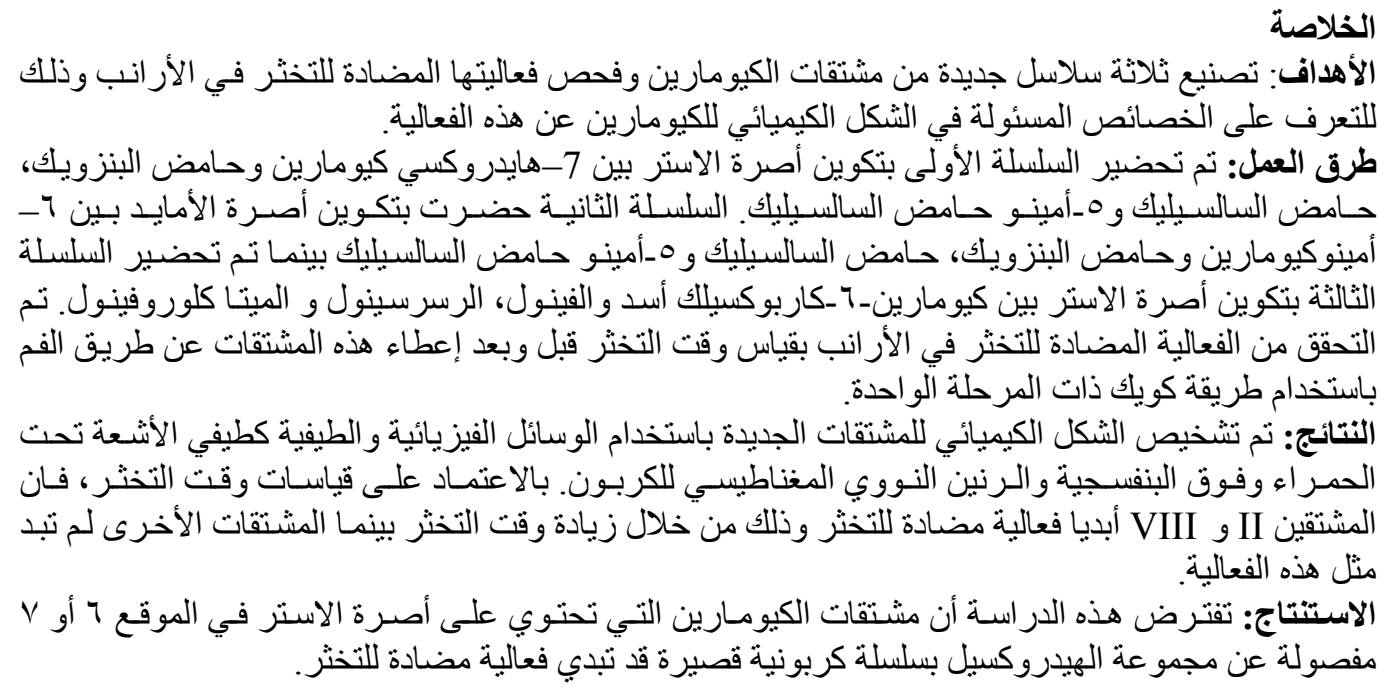


C oumarins owe their class name to 'Coumarou', the vernacular name of the Tonka bean, from which coumarin itself was isolated in 1820. Coumarin is classified as a member of the benzopyrone family of compounds, all of which consist of a benzene ring joined to a pyrone ring ${ }^{1}$. The coumarin chemistry has become more and more important over the years, which is documented by thousands of papers and patents. This is mainly because of the discovery of their varied biochemical properties ${ }^{2}$.

Coumarin derivatives have been reported to possess a wide range of pharmacological activities such as anticoagulant, ${ }^{3}$ anti-inflammatory, ${ }^{4}$ antimicrobial, ${ }^{5} \quad$ antitubercular, ${ }^{6}$ antioxidant $^{7}$, analgesic ${ }^{8}$, and cytotoxic activities ${ }^{9}$.

The coumarin-type anticoagulants have been used for the prophylaxis and treatment of thromboembolic disorders for more than 50 years. ${ }^{10}$ Coumarins are vitamin $\mathrm{K}$ antagonists and inhibit the hepatic synthesis of blood clotting factors II (prothrombin), VII, IX and X as well as of anticoagulant proteins $\mathrm{C}$ and $\mathrm{S}$ from their precursor proteins. These precursors are activated by vitamin $\mathrm{K}$, which is initially reduced to its hydroquinone form and is then reversibly converted to its 2,3-epoxide form. Coumarins block the enzymatic regeneration of the hydroquinone form, reducing the amount of biologically active vitamin $\mathrm{K}$ and causing an accumulation of inactive precursors of the blood clotting factors ${ }^{11}$. In addition, coumarins inhibit a variety of other vitamin K-dependent carboxylation reactions in the kidneys, placenta and bones $^{12}$.

Prothrombin time (PT) has been used to monitor oral anticoagulant therapy since the introduction of warfarin in $1941^{13}$. This test measures the clotting time of plasma in the presence of an optimal amount of tissue extract (thromboplastin) and depends on the reactions with factors $\mathrm{V}$, VII, $\mathrm{X}$ and on the fibrinogen concentration in the plasma indicating the overall efficiency of extrinsic clotting pathway ${ }^{14}$.

The PT assay is performed by the addition of calcium and thromboplastin to citrated plasma. Thromboplastin is a phospholipid-protein extract of tissue (usually lung, brain, or placenta) that contains both the tissue factor and phospholipids necessary to promote the activation of factor X by factor VII ${ }^{15}$.

The focus of the presented study was to synthesize three series of new coumarins; each series consists of three derivatives and to quantify their anticoagulant activity in rabbits depending on PT measurements before and after oral administration.

\section{Experimental}

The parent coumarins with $99 \%$ purity were obtained from Aldrich Chemical Company. The other chemicals and solvents used in this study were of analytical grade purity.

The melting points were measured using an electro-thermal CIA 9300 apparatus and were reported uncorrected. The IR spectra were recorded on a Buck 500 scientific FTIR spectrophotometer using $\mathrm{KBr}$ disc.

Ultraviolet-visible spectra were obtained via Carrywinn U.V. Varian U.V. - visible spectrophotometer.

The ${ }^{13} \mathrm{C}$ NMR spectra were recorded on $300 \mathrm{MHz}$ JOEL NMR AL300 using TMS as a standard and $\mathrm{CDCl}_{3}$ as a solvent; the chemical shifts were given in part per million ( $\mathrm{ppm}$ ). These spectra were measured in Sweden. The chemical structures were drawn by Chemdraw Office 2001 software. 
The follow up of reaction and the purity of each products were carried out on precoated TLC plates (silica $60 \mathrm{~F}_{254}$, Merck); the solvent system was chloroform: acetone (4:1); the spots were visualized in ultraviolet light. The reagent (thromboplastincalcium chloride) for determination of PT was purchased from Biolab SA Company (France).

Synthesis of series 1 derivatives ${ }^{16}$

Intimate mixture of benzoic acid derivative $(0.025 \mathrm{~mol})$, 7-hydroxy coumarin $(4.05 \mathrm{~g}, 0.025 \mathrm{~mol})$, benzene $(80 \mathrm{ml})$ and catalytic amount of concentrated sulfuric acid was refluxed for $4 \mathrm{hr}$. The reaction mixture was then cooled to $15-20^{\circ} \mathrm{C}$; the crude product was crystallized out, filtered off and treated with diluted $\mathrm{NaHCO}_{3}$ solution.

The crystals washed thoroughly with cold water, dried and recrystallized from ethanol. The synthetic pathway of these derivatives is summarized in Scheme 1 while their physicochemical properties are listed in Table 1.

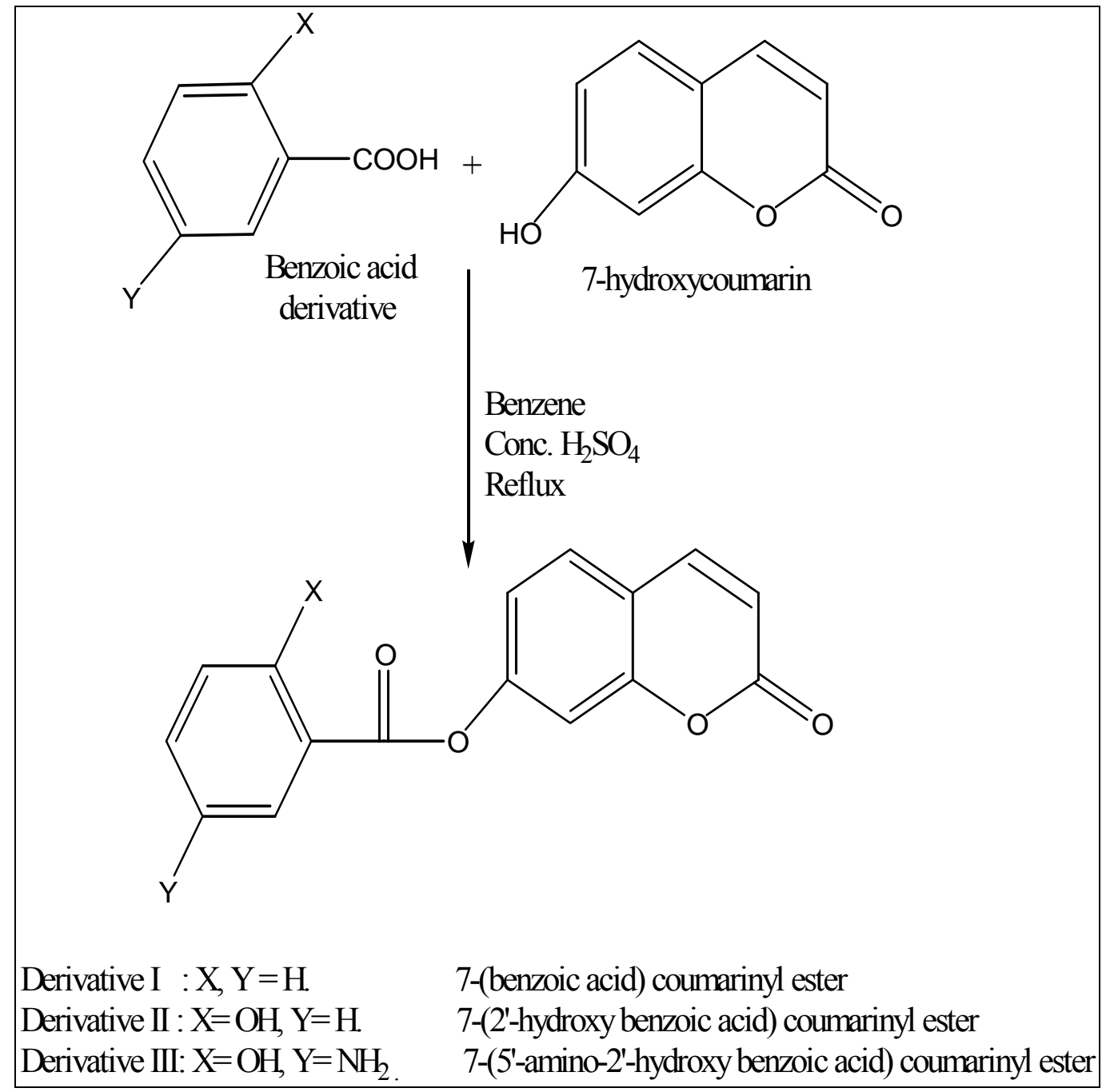

Scheme 1. Synthetic pathway of series 1 derivatives 
Synthesis of series 2 derivatives ${ }^{17}$

The mixture of benzoic acid derivative (0.025 mol), 6-aminocoumarin (4.025 g, $0.025 \mathrm{~mol})$, thionyl chloride $(2.2 \mathrm{ml}$, $0.03 \mathrm{~mol})$ and benzene $(30 \mathrm{ml})$ were refluxed for $2 \mathrm{hr}$. Then the mixture was poured into a conical flask contained $500 \mathrm{ml}$ of an ice water.

The precipitate was filtered off, dissolved in $25 \mathrm{ml}$ of $2 \mathrm{~N}$ sodium hydroxide solution and filtered again. The solution was acidified with $2 \mathrm{~N}$ hydrochloric acid, filtered by suction, washed with cold water, dried and recrystallized from ethanol. The synthetic pathway of these derivatives is summarized in Scheme 2 while their physicochemical properties are listed in Table 1.

Synthesis of series 3 derivatives ${ }^{18}$ In a water bath, coumarin-6-carboxylic acid (10.15 gm, $0.035 \mathrm{~mol})$ and an excess of thionyl chloride were refluxed for $1.5 \mathrm{hr}$. The excess amount of thionyl chloride was removed under vacuum to give coumarin-6-carbonyl chloride.

From a dropping funnel, benzene $(25 \mathrm{ml})$ was added dropwise to a mixture of coumarin-6-carbonyl chloride (7.725 gm, $0.025 \mathrm{~mol})$ and phenolic derivative $(0.025 \mathrm{~mol})$. The reaction mixture was stirred at room temperature for $30 \mathrm{~min}$, refluxed for 2 $\mathrm{hr}$ and then neutralized with ice cold diluted $\mathrm{HCl}$.

The precipitate was filtered off, washed with cold water, dried and recrystallized from ethanol. The synthetic pathway of these derivatives is summarized in Scheme 3 while their physicochemical properties are listed in Table 1.

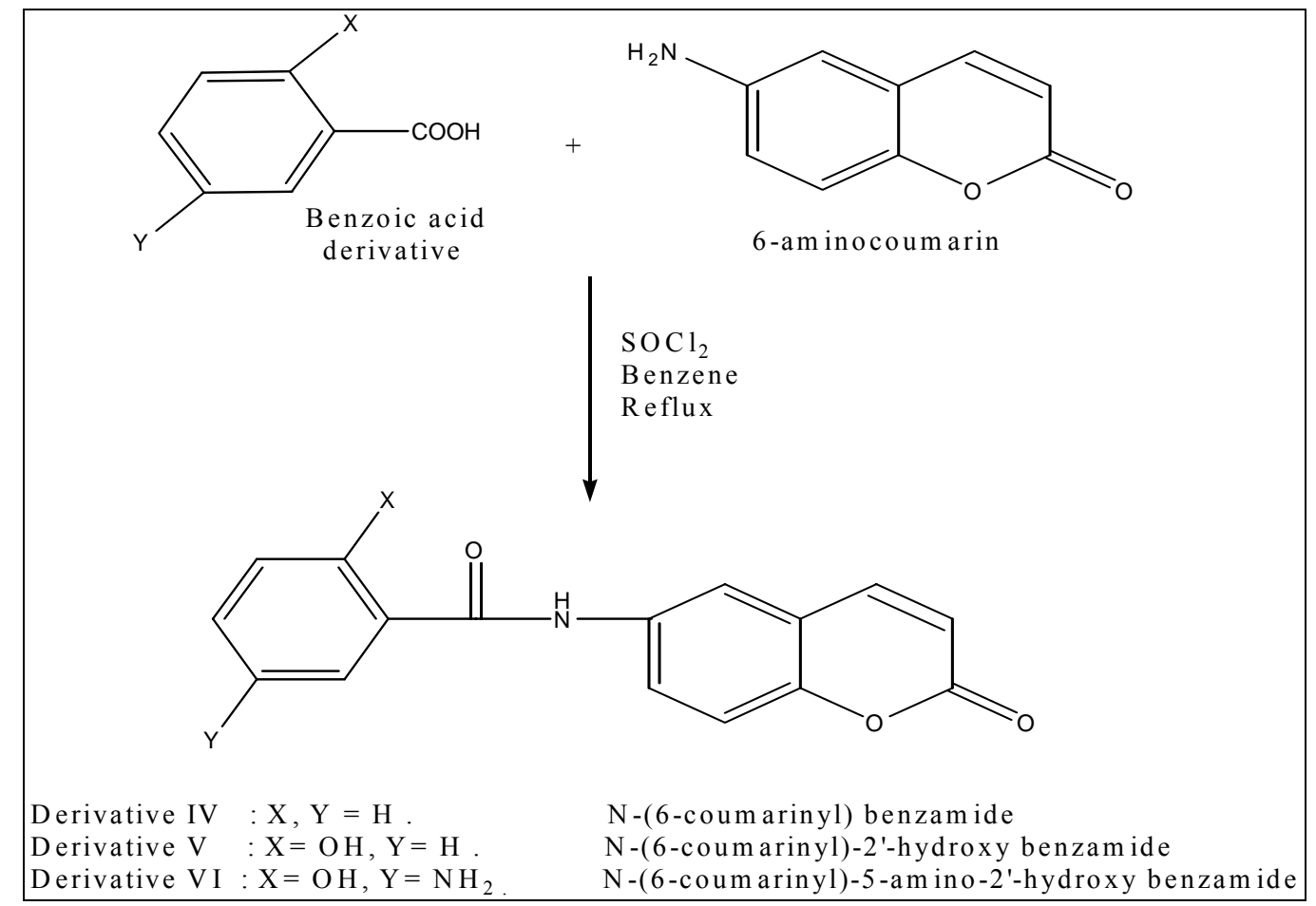

Scheme 2. Synthetic pathway of series 2 derivatives 


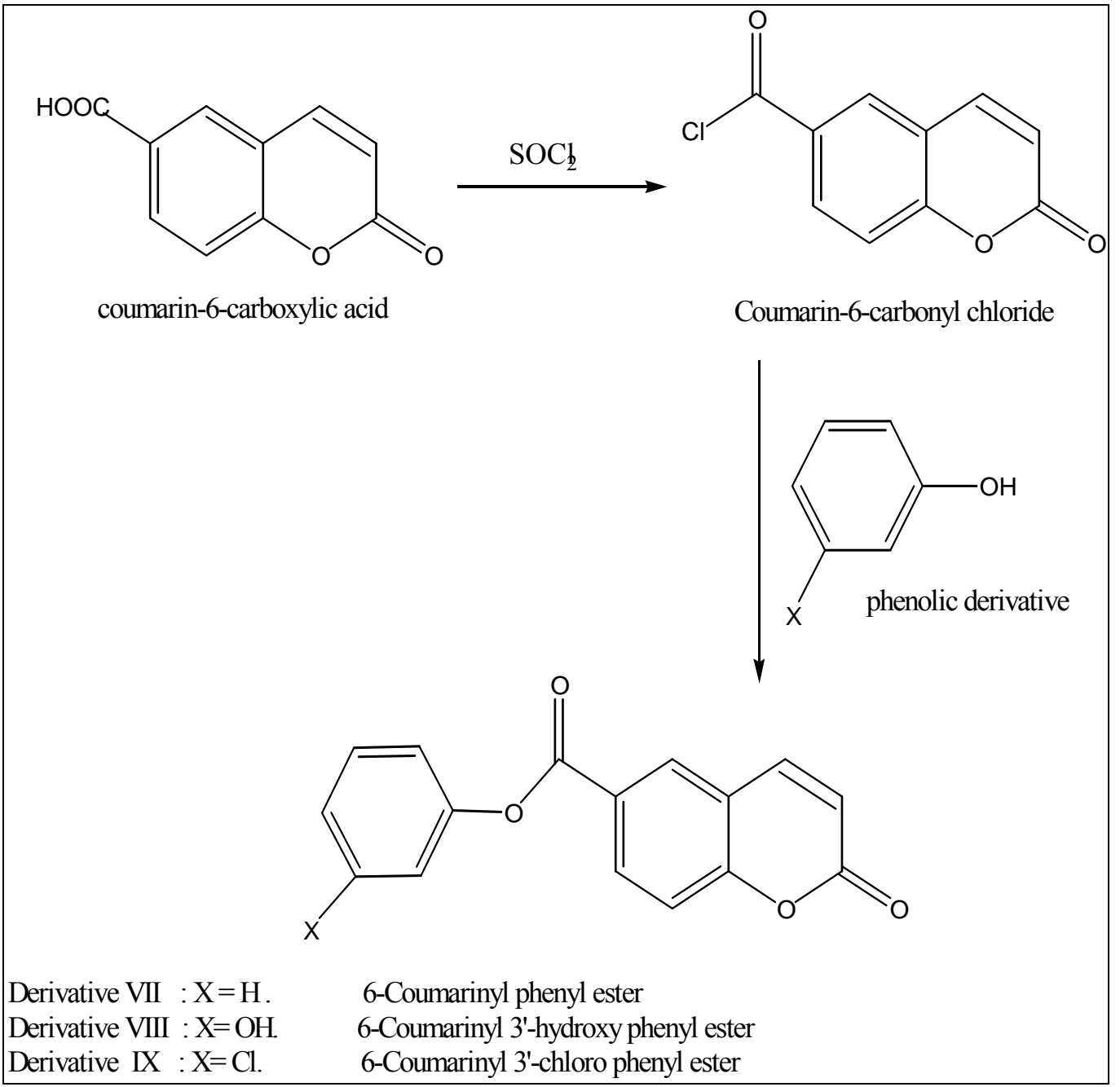

Scheme 3. Synthetic pathway of series 3 derivatives

Table 1. The physicochemical properties of new coumarin derivatives

\begin{tabular}{|c|c|c|c|c|}
\hline $\begin{array}{c}\text { Derivative } \\
\text { number }\end{array}$ & m.p. $\left({ }^{\circ} \mathrm{C}\right)$ & $\%$ yield & $\mathrm{R}_{\mathrm{f}}$ & $\begin{array}{c}\lambda_{\max }(\text { ethanol }) \\
\mathrm{nm}\end{array}$ \\
\hline I & $156-158$ & 51.03 & 0.60 & 372 \\
\hline II & $191-193$ & 46.87 & 0.55 & 316 \\
\hline III & $259-261$ & 44.37 & 0.42 & 323 \\
\hline IV & $341-343$ & 73.22 & 0.59 & 346 \\
\hline V & $311-313$ & 77.15 & 0.52 & 381 \\
\hline VI & $325-327$ & 65.56 & 0.48 & 392 \\
\hline VII & $212-214$ & 78.81 & 0.49 & 335 \\
\hline VIII & $236-238$ & 73.98 & 0.58 & 329 \\
\hline IX & $199-201$ & 71.02 & 0.50 & 375 \\
\hline
\end{tabular}




\section{Anticoagulant activity}

The anticoagulant activity of the new coumarins was tested by determining the PT via the one-stage method of Quick as followed ${ }^{19}$.

A $(0.9 \mathrm{ml})$ of rabbit blood was mixed with $0.1 \mathrm{ml}$ of $0.1 \mathrm{M}$ sodium citrate solution. The resulted mixture was then centrifuged at $3000 \mathrm{rpm}$ for 15 min. The separated plasma was transferred to a test tube kept in a water bath at $37 \pm 0.5^{\circ} \mathrm{C}$.

In another test tube, $(0.2 \mathrm{ml})$ of thromboplastin-calcium chloride mixture was allowed to warm in the same water bath for $15 \mathrm{~min}$ and then $(0.1 \mathrm{ml})$ of warmed plasma was added. Simultaneously, the stop-watch was worked and the test tube was kept in a water bath for 10 seconds with gentle shaking. Then the test tube removed from the water bath, holed in front of bright light and tilted slightly until a solid gel clot would appear. The time from addition of plasma to the thromboplastin-calcium chloride mixture until the clot would appear represents the PT. This assay was carried out for each of plasma sample in duplicate ${ }^{20,21}$.

\section{Results and discussion}

Coumarin and coumarin-related compounds have proved for many years to have a significant therapeutic potential $^{22}$. They come from a wide variety of natural sources and new coumarin derivatives are being discovered or synthesized on a regular basis. ${ }^{23}$ During the continuous effort to detect the structural characteristics of coumarin nucleus that are responsible for anticoagulant activity, we thought it worthwhile to synthesize new coumarin derivatives and to screen their anticoagulant activity by using Quick's one-stage method.

\section{Synthesis of series 1 derivatives}

The derivatives of series 1 were synthesized by the formation of an ester linkage between 7 hydroxycoumarin (Umbelliferone) and benzoic acid derivatives in a strong acidic medium. Strong liquid mineral acids as $\mathrm{H}_{2} \mathrm{SO}_{4}$ are effective esterifying agents and their role in an esterification are the subjects of extensive studies. For instance, it has been well documented that when using this type of catalyst, the slow step of the reaction is the nucleophilic attack of the phenol on the protonated carbonyl group of the carboxylic acid ${ }^{24}$.

This mechanistic route first involves protonation of the carboxylic acid, which activates it for reaction with non protonated phenol to yield a tetrahedral intermediate that, by decomposition, produces the products of reaction; ester and water. ${ }^{25}$

The general structure of series 1 derivatives is shown in Figure 1, the ${ }^{13} \mathrm{C}$ NMR spectra of these derivatives are summarized in Table 2 while their IR spectra are listed in Table 3.

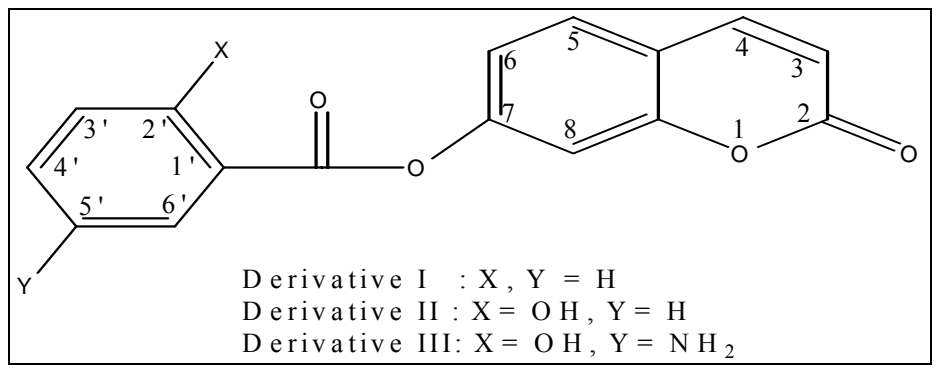

Figure 1. The general structure of series 1 derivatives 
Table 2. The data obtained from ${ }^{13} \mathrm{C}$ NMR spectra of series 1 derivatives

\begin{tabular}{|c|c|c|c|c|c|c|c|}
\hline \multirow{2}{*}{$\begin{array}{c}\text { Derivative } \\
\text { number }\end{array}$} & \multicolumn{7}{|c|}{ The carbon chemical shift $\left(\mathrm{CDCl}_{3}, \delta, \mathrm{ppm}\right)$} \\
\cline { 2 - 8 } & $\begin{array}{c}\text { Position } \\
2\end{array}$ & $\begin{array}{c}\text { Position } \\
3\end{array}$ & $\begin{array}{c}\text { Position } \\
4\end{array}$ & $\begin{array}{c}\text { Position } \\
7\end{array}$ & $\begin{array}{c}\text { Position } \\
2^{\prime}\end{array}$ & $\begin{array}{c}\text { Position } \\
5{ }^{\prime}\end{array}$ & $\begin{array}{c}\text { Aliphatic } \\
\text { carbonyl }\end{array}$ \\
\hline I & 167.76 & 129.12 & 141.11 & 148.98 & 128.65 & 126.12 & 159.55 \\
\hline II & 169.12 & 126.67 & 144.57 & 150.34 & 156.87 & 121.80 & 163.81 \\
\hline III & 170.22 & 125.88 & 143.76 & 150.77 & 149.12 & 139.77 & 164.09 \\
\hline
\end{tabular}

Table 3. The data obtained from IR spectra of series 1 derivatives

\begin{tabular}{|c|c|c|c|c|c|c|}
\hline \multirow{2}{*}{$\begin{array}{c}\text { Derivative } \\
\text { number }\end{array}$} & \multicolumn{6}{|c|}{ The stretching absorption band $\left(\mathrm{KBr}, \mathrm{v}, \mathrm{cm}^{-1}\right)$} \\
\hline & $\begin{array}{r}\mathrm{C}=\mathrm{O} \text { of } \\
\begin{array}{r}\text { Aliphatic } \\
\text { ester }\end{array}\end{array}$ & $\begin{array}{c}\mathrm{C}=\mathrm{O} \text { of } \\
\alpha- \\
\text { pyrone }\end{array}$ & $\begin{array}{c}\mathrm{C}-\mathrm{H} \\
\text { aromatic }\end{array}$ & $\begin{array}{c}\mathrm{C}=\mathrm{C} \text { of } \\
\alpha- \\
\text { pyrone }\end{array}$ & $\begin{array}{c}\text { O-H } \\
\text { intermolecular } \\
\text { hydrogen } \\
\text { bonded }\end{array}$ & $\begin{array}{l}\text { N-H of } \\
\text { primary } \\
\text { amine }\end{array}$ \\
\hline I & $\begin{array}{c}1731.12 \\
\text { (s) }\end{array}$ & $\begin{array}{c}1723.65 \\
\text { (s) }\end{array}$ & $\begin{array}{c}3045.08 \\
(\mathrm{w})\end{array}$ & $\begin{array}{c}1662.23 \\
\text { (s) }\end{array}$ & ---------- & \\
\hline II & $\begin{array}{c}1729.76 \\
\text { (s) }\end{array}$ & $\begin{array}{c}1719.87 \\
\text { (s) }\end{array}$ & $\begin{array}{c}3052.43 \\
\text { (w) }\end{array}$ & $\begin{array}{c}1665.01 \\
\text { (s) }\end{array}$ & $\begin{array}{c}3371.29 \\
\text { (br) }\end{array}$ & -------- \\
\hline III & $\begin{array}{c}1732.83 \\
\text { (s) }\end{array}$ & $\begin{array}{c}1724.66 \\
(\mathrm{~s})\end{array}$ & $\begin{array}{c}3051.17 \\
(\mathrm{w})\end{array}$ & $\begin{array}{c}1670.12 \\
(\mathrm{~s})\end{array}$ & $\begin{array}{c}3378.66 \\
\text { (br) }\end{array}$ & $\begin{array}{c}3423.84 \\
\text { (m) }\end{array}$ \\
\hline
\end{tabular}

$\mathrm{s}=$ strong, $\mathrm{w}=$ weak, $\mathrm{br}=$ broad, $\mathrm{m}=$ medium .

\section{Synthesis of series 2 derivatives}

The derivatives of series 2 were synthesized by treating the benzoic acid derivatives with thionyl chloride to yield corresponding acid chloride derivatives which were directly reacted with 6-aminocoumarin to give amide derivatives.

Thionyl chloride is the most popular reagent for preparation of acid chlorides with many advantages as it is a volatile substance and the excess amount of it can be distilled off at the end of reaction. ${ }^{26}$ Only gaseous byproducts are given out and no tedious workup is required for purification of acid chlorides ${ }^{27}$. It reacts also with sterically hindered carboxylic acids and works well in the variety of conditions $^{28}$.

The general structure of series 2 derivatives is shown in Figure 2, the ${ }^{13} \mathrm{C}$ NMR spectra of these derivatives are summarized in Table 4 while their IR spectra are listed in Table 5. 


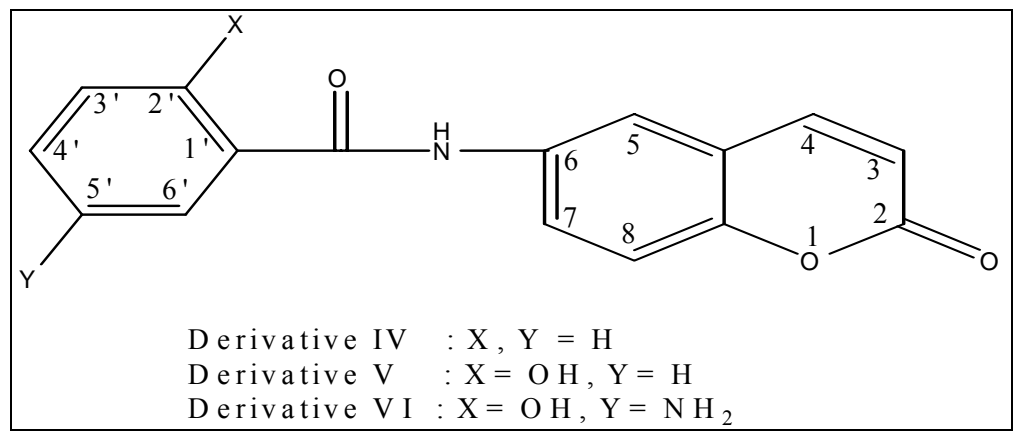

Figure 2. The general structure of series 2 derivatives

Table 4. The data obtained from ${ }^{13} \mathrm{C}$ NMR spectra of series 2 derivatives

\begin{tabular}{|c|c|c|c|c|c|c|c|}
\hline \multirow{2}{*}{$\begin{array}{c}\text { Derivative } \\
\text { number }\end{array}$} & \multicolumn{7}{|c|}{ The carbon chemical shift $\left(\mathrm{CDCl}_{3}, \delta, \mathrm{ppm}\right)$} \\
\cline { 2 - 8 } & $\begin{array}{c}\text { Position } \\
2\end{array}$ & $\begin{array}{c}\text { Position } \\
3\end{array}$ & $\begin{array}{c}\text { Position } \\
4\end{array}$ & $\begin{array}{c}\text { Position } \\
6\end{array}$ & $\begin{array}{c}\text { Position } \\
2^{\prime}\end{array}$ & $\begin{array}{c}\text { Position } \\
5{ }^{\prime}\end{array}$ & $\begin{array}{c}\text { Aliphatic } \\
\text { carbonyl }\end{array}$ \\
\hline IV & 166.06 & 125.09 & 142.67 & 134.52 & 128.65 & 126.12 & 161.25 \\
\hline V & 170.33 & 126.01 & 144.12 & 133.01 & 156.87 & 121.80 & 158.38 \\
\hline VI & 169.35 & 128.44 & 144.34 & 135.98 & 149.12 & 139.77 & 158.11 \\
\hline
\end{tabular}

Table 5. The data obtained from IR spectra of series 2 derivatives

\begin{tabular}{|c|c|c|c|c|c|c|c|}
\hline \multirow{2}{*}{$\begin{array}{c}\text { Derivative } \\
\text { number }\end{array}$} & \multicolumn{7}{|c|}{ The stretching absorption band $\left(\mathrm{KBr}, v, \mathrm{~cm}^{-1}\right)$} \\
\hline & $\begin{array}{c}\mathrm{C}=\mathrm{O} \text { of } \\
\alpha- \\
\text { pyrone }\end{array}$ & $\begin{array}{l}\mathrm{N}-\mathrm{H} \text { of } \\
\text { amide } \\
\text { (H- } \\
\text { bonded) }\end{array}$ & $\begin{array}{c}\mathrm{C}=\mathrm{O} \text { of } \\
\text { amide }\end{array}$ & $\begin{array}{c}\mathrm{C}-\mathrm{H} \\
\text { aromatic }\end{array}$ & $\begin{array}{c}\mathrm{C}=\mathrm{C} \text { of } \\
\alpha- \\
\text { pyrone }\end{array}$ & $\begin{array}{c}\text { O-H } \\
\text { inter- } \\
\text { molecular } \\
\text { H- } \\
\text { bonded }\end{array}$ & $\begin{array}{l}\text { N-H of } \\
\text { primary } \\
\text { amine }\end{array}$ \\
\hline IV & $\begin{array}{c}1734.1 \\
(\mathrm{~s})\end{array}$ & $\begin{array}{c}3215.2 \\
(\mathrm{~m})\end{array}$ & $\begin{array}{c}1648.5 \\
(\mathrm{~m})\end{array}$ & $\begin{array}{c}3051.0 \\
(\mathrm{w})\end{array}$ & $\begin{array}{c}1660.3 \\
(\mathrm{~s})\end{array}$ & ---------- & --------- \\
\hline V & $\begin{array}{c}1731.1 \\
\text { (s) }\end{array}$ & $\begin{array}{c}3213.7 \\
(\mathrm{~m})\end{array}$ & $\begin{array}{c}1649.8 \\
(\mathrm{~m})\end{array}$ & $\begin{array}{c}3058.4 \\
(\mathrm{w})\end{array}$ & $\begin{array}{c}1662.0 \\
\text { (s) }\end{array}$ & $\begin{array}{c}3381.2 \\
\text { (br) }\end{array}$ & -------- \\
\hline VI & $\begin{array}{c}1730.9 \\
\text { (s) }\end{array}$ & $\begin{array}{c}3222.1 \\
(\mathrm{~m})\end{array}$ & $\begin{array}{c}1651.0 \\
(\mathrm{~m})\end{array}$ & $\begin{array}{c}3056.7 \\
(\mathrm{w})\end{array}$ & $\begin{array}{c}1667.6 \\
\text { (s) }\end{array}$ & $\begin{array}{c}3371.3 \\
\text { (br) }\end{array}$ & $\begin{array}{c}3441.3 \\
(\mathrm{~m})\end{array}$ \\
\hline
\end{tabular}

$\mathrm{s}=$ strong, $\mathrm{w}=$ weak, br= broad, $\mathrm{m}=$ medium.

\section{Synthesis of series 3 derivatives}

The derivatives of series 3 were synthesized by treating coumarin-6carboxylic acid with thionyl chloride to yield a corresponding acid chloride derivative which was directly reacted with phenolic derivatives to give the final ester products.

The preparation of esters from their corresponding carboxylic acids is an important and well-known transformation reaction in organic synthesis. This preparation requires an activation of the carboxyl group; which can be achieved by converting it to more reactive functional group as acyl halide $^{29,30}$.

The general structure of series 3 derivatives is shown in Figure 3, the ${ }^{13} \mathrm{C}$ NMR spectra of these derivatives are summarized in Table 6 while their IR spectra are listed in Table 7. 


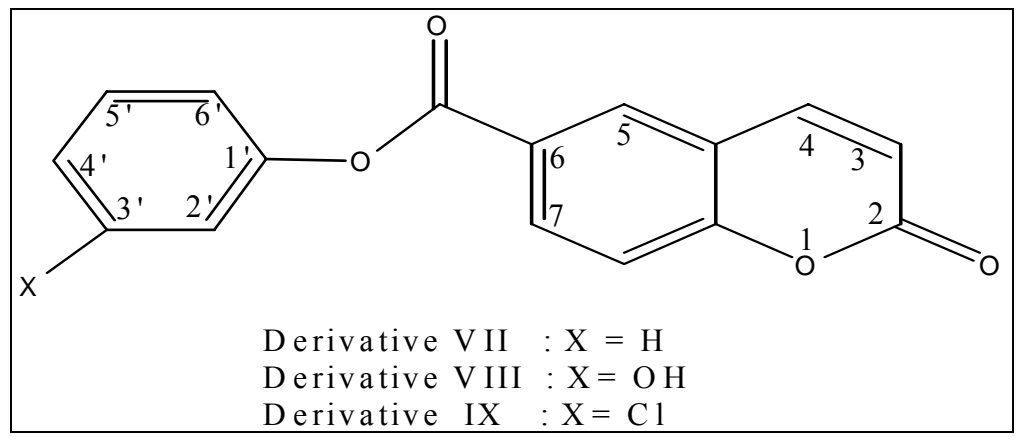

Figure 3 . The general structure of series 3 derivatives

Table 6. The data obtained from ${ }^{13} \mathrm{C}$ NMR spectra of series 3 derivatives.

\begin{tabular}{|c|c|c|c|c|c|c|c|}
\hline \multirow{2}{*}{$\begin{array}{c}\text { Derivative } \\
\text { number }\end{array}$} & \multicolumn{7}{|c|}{ The carbon chemical shift $\left(\mathrm{CDCl}_{3}, \delta, \mathrm{ppm}\right)$} \\
\cline { 2 - 8 } & $\begin{array}{c}\text { Position } \\
2\end{array}$ & $\begin{array}{c}\text { Position } \\
3\end{array}$ & $\begin{array}{c}\text { Position } \\
4\end{array}$ & $\begin{array}{c}\text { Position } \\
6\end{array}$ & $\begin{array}{c}\text { Position } \\
1^{\prime}\end{array}$ & $\begin{array}{c}\text { Position } \\
3^{\prime}\end{array}$ & $\begin{array}{c}\text { Aliphatic } \\
\text { carbonyl }\end{array}$ \\
\hline VII & 168.16 & 127.19 & 138.67 & 128.34 & 155.42 & 138.18 & 167.15 \\
\hline VIII & 169.26 & 128.88 & 140.45 & 126.05 & 156.22 & 160.74 & 165.91 \\
\hline XI & 169.22 & 125.01 & 137.06 & 126.67 & 156.10 & 128.16 & 162.02 \\
\hline
\end{tabular}

Table 7. The data obtained from IR spectra of series 3 derivatives.

\begin{tabular}{|l|c|c|c|c|c|c|}
\hline \multirow{3}{*}{$\begin{array}{c}\text { Derivative } \\
\text { number }\end{array}$} & \multicolumn{6}{|c|}{ The stretching absorption band $\left(\mathrm{KBr}, v, \mathrm{~cm}^{-1}\right)$} \\
\cline { 2 - 7 } & $\begin{array}{c}\mathrm{C}=\mathrm{O} \text { of } \\
\text { aliphatic } \\
\text { ester }\end{array}$ & $\begin{array}{c}\mathrm{C}=\mathrm{O} \text { of } \\
\alpha \text { - pyrone }\end{array}$ & $\begin{array}{c}\mathrm{C}-\mathrm{H} \\
\text { aromatic }\end{array}$ & $\begin{array}{c}\mathrm{C}=\mathrm{C} \text { of } \\
\alpha \text { - pyrone }\end{array}$ & Free O-H & $\mathrm{C}-\mathrm{Cl}$ \\
\hline VII & $\begin{array}{c}1733.33 \\
(\mathrm{~s})\end{array}$ & $\begin{array}{c}1720.87 \\
(\mathrm{~s})\end{array}$ & $\begin{array}{c}3067.62 \\
(\mathrm{w})\end{array}$ & $\begin{array}{c}1672.01 \\
(\mathrm{~s})\end{array}$ & --------- & ------- \\
\hline VIII & $\begin{array}{c}1734.45 \\
(\mathrm{~s})\end{array}$ & $\begin{array}{c}1722.08 \\
(\mathrm{~s})\end{array}$ & $\begin{array}{c}3069.61 \\
(\mathrm{w})\end{array}$ & $\begin{array}{c}1666.14 \\
(\mathrm{~s})\end{array}$ & $\begin{array}{c}3592.22 \\
(\mathrm{~s})\end{array}$ & -------- \\
\hline XI & 1735.01 & $\begin{array}{c}1724.00 \\
(\mathrm{~s})\end{array}$ & $\begin{array}{c}3066.28 \\
(\mathrm{w})\end{array}$ & $\begin{array}{c}1672.62 \\
(\mathrm{~s})\end{array}$ & --------- & $\begin{array}{c}1091.2 \\
(\mathrm{~s})\end{array}$ \\
\hline
\end{tabular}

$\mathrm{s}=$ strong, $\mathrm{w}=$ weak.

\section{Anticoagulant activity}

After specifying the normal PT, the 45 rabbits were divided into groups of five members. The rabbits of a specific group were given single doses (40 $\mathrm{mg}$ /day) by mouth through a small rubber catheter passing a mouth-gag of selected coumarin derivative that dissolved in $2 \mathrm{ml}$ of corn oil for three consequence days. The treated rabbits were observed for the first three hours after treatment for the occurrence of poisoning signs.

After 72 hours from the first oral dose, the PT was determined again. It seems appropriate to wait this period of time because of the clearance time of some clotting factors, such as for factor $\mathrm{X}$ of about 40 hours and for factor II (prothrombin) of about 60 hours ${ }^{31}$. The PT data before and after oral administration of new coumarins are listed in Table 8. 
Table 8. The data obtained from prothrombine time measurements

\begin{tabular}{|c|c|c|}
\hline $\begin{array}{c}\text { Derivative } \\
\text { number }\end{array}$ & $\begin{array}{c}\text { The mean of PT in seconds for } \\
\text { five rabbits before treatment }\end{array}$ & $\begin{array}{c}\text { The mean of PT in seconds for } \\
\text { five rabbits after treatment }\end{array}$ \\
\hline I & 15.76 & 15.22 \\
\hline II & 14.56 & 19.83 \\
\hline III & 14.89 & 14.73 \\
\hline VI & 14.11 & 14.36 \\
\hline V & 13.98 & 14.13 \\
\hline VI & 14.57 & 14.36 \\
\hline VII & 13.86 & 14.23 \\
\hline VIII & 14.49 & 20.01 \\
\hline XI & 14.45 & 14.31 \\
\hline
\end{tabular}

The determination of PT has gained a wide laboratory and clinical acceptance over the last 15 years as a standard of measurement on which clinical treatment with the coumarin derivatives is based ${ }^{32}$. PT measures the effect of a reduction in vitamin $\mathrm{K}$ dependent coagulation factors II, V, VII and $\mathrm{X}$ and indicates the integrity of the extrinsic coagulation pathway ${ }^{33}$.

The normal PT value ranges from 14-16 seconds ${ }^{34}$ and the change of more than two seconds in its controlled value after oral administration may be considered as a significant change ${ }^{35}$, according to that, derivatives II and VIII were found to exhibit a promising anticoagulant activity. Rabbit was used in the presented work as a model to screen the anticoagulant activity of new coumarins because of the similarity in coumarin metabolism in both human and rabbit ${ }^{36}$. The variability in the PT before and after oral administration of derivatives II and VIII is explained in Figure 4.

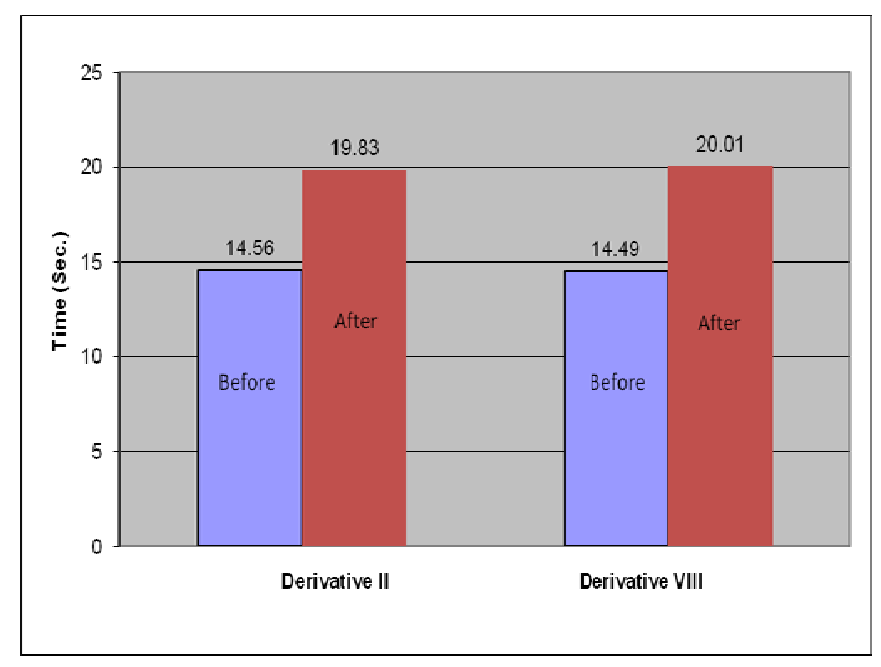

Figure 4. The prothrombin time values of derivatives II and VIII before and after treatment 


\section{Conclusion}

In the present work, three series of new coumarin derivatives were synthesized in moderate to high yield and their chemical structures were established by physical and spectroscopic techniques as FTIR, UV and ${ }^{13} \mathrm{C}-\mathrm{NMR}$ spectra. The anticoagulant activity of these derivatives was investigated by determining the PT in groups of rabbits according to Quick's one-stage method.

The results revealed that only derivatives II and VIII showed a promising anticoagulant activity through increasing the clotting time. Depending on the chemical structure of new coumarins, the presented work proposed that the coumarin derivative contained an ester linkage at position 6 or 7 separated from a hydroxyl group by short carbon side chain may show anticoagulant activity. It is believed that this work may represent a one stone in the building of structureactivity relationship of coumarins.

\section{References}

1. Aoife L, Richard K. Studies on coumarins and coumarin-related compounds to determine their therapeutic role in the treatment of cancer. Current Pharm Des 2004;10:3797-811.

2. Sanket PC, Nandini RP. Synthesis of biologically active 4-coumarin6-yl(amino)-5-coumarin-3-yl-3phenyl-1,2,4oxadia- zolines. Indian J Chem 2009;48B:286-90.

3. Rakesh C, Pitre KS. Structural modification of coumarin for its increased anticoagulation potency. Canadian J Chem Engin \& Technol 2010;1(2):7-15.

4. Ghate M, Manohar D, Kulkarni MV, et al. Synthesis of vanillin ethers from 4-(bromomethyl) coumarin as anti-inflammatory agents. Eur J Med Chem 2003;38:297-302.
5. Khan IA, Kulkarni MV, Gopal M, et al. Synthesis and biological evaluation of novel angularly fused polycyclic coumarin. Bioorg Med Chem Lett 2005;15:3584-7.

6. Silvia HC, Milena BB, Maria CS, et al. Antitubercular activity of new coumarins. Chem Biol \& Drug Des 2011;77:489-93.

7. Parames WM, Thengungal KR, Gopal KS. Synthesis of coumarin heterocyclic derivatives with antioxidant activity and in vitro cytotoxic activity against tumor cells. Acta Pharm 2009;59:159-70.

8. Manjunath G, Kusanur RA, Kulkarni MV. Synthesis and in vivo analgesic and antiinflammatory activity of some biheterocyclic coumarin derivatives. Eur J Med Chem 2005;40:882-7.

9. Masmi K, Hiroshi S, Noboru M, et al. Coumarin derivatives with tumor-specific cytotoxicity and multi-drug resistance reversal activity. In Vivo 2005;19:705-712.

10.Van Schie MR, Wadelius M, Kamali F, et al. Genotype-guided dosing of coumarin derivatives: the European pharmacogenetics of anticoagulant therapy trial design. Pharmacogenomics 2009;10(10):1287-1295.

11. Oldenburg J, Marinova M, MullerReible C, et al. The vitamin K cycle. Vitam Horm 2008;78:53-62.

12.Berkner KL. Vitamin K-dependent carboxylation. Vitam Horm 2008;78:131-5.

13. Olson JD, Brandt JT, Chandler WL, et al. Laboratory reporting of the international normalized ratio. Arch Pathol Lab Med 2007;131:1641-7.

14. Manfred K, Caroline S. Determination of Coumarin-type anticoagulants in human plasma by HPLC electrospray ionization 
tandem mass spectrometry with an ion trap detector. Clin Chem 2002;48(1):84-91.

15.Poller L. Progress in standardization in anticoagulant control. Hematol Rev 1987;1:22541.

16. Mashelkar UC, Audi AA. Synthesis of some novel 4substituted coumarins having potential biological activity (part III). Indian J Chem 2006;45B:1463-9.

17.Wolfang S, El-soyed B, Gerhard H, et al. Malonates in cyclocondensation reactions. Molecules 2001;6:338-352.

18. Yoshimi H, Hiroshi H, Takashi Y, et al. Synthesis and structureactivity relationships of 4-Amino5-chloro-N-(1,4-dialkylhexahydro1,4-diazepin-6-yl)-2methoxybenzamide derivatives, novel and potent serotonin $5-\mathrm{HT}_{3}$ and dopamine $\mathrm{D}_{2}$ receptors dual antagonist. Chem Pharm Bull 2002;50:941-59.

19. Mizoguchi Y, Matsuoka T, Mizuguchi $\mathrm{H}$, et al. Changes in blood parameters in New Zealand white rabbits during pregnancy. Lab Anim 2010;44(1):33-9.

20.Siroka ZB, Krocilova B, Pikula J, et al. Blood coagulation parameters in fallow deer. Veter Med 2011;56(3):119-22.

21.Olorunshola KV, Achie LN, Malik HL, et al. Prothrombin time, clothing time, platelet concentration and haematocrit during labor and postpartum of women in Zaria. Asian J Med Sci 2011;3(4):170-5.

22.Budzisz E, Brzezinska E, Krajewska U, et al. Cytotoxic effects, alkylating properties and molecular modeling of coumarin derivatives and their phosphonic analogues. Eur J Med Chem 2003;38:597-603.

23. Mousa S. Anticoagulants in thrombosis and cancer. Expert Rev Anticancer Ther 2002;2:227-33.

24. Yijun L, Edgar L, James G, et al. A comparison of the esterification of acetic acid with methanol using heterogeneous versus homogeneous acid catalysis. J Catal 2006;242:278-86.

25. Bhimashankar RP, Hanumant G, Vijay VB. Ethyl acetate synthesis by esterification of acetic acid with ethanol over a heteropolyacid on montmorillonite $\mathrm{K}_{10}$. Indian J Streams Res 2011;1:227-31.

26. Velingkar VS, Dandekar VS, Murugananthan K. Synthesis and pharmacological evaluation of some novel potent type II antidiabetic agents. Inter $\mathbf{J}$ Pharm Pharmaceut Sci 2009:1:149-58.

27. Nagaraja N, Vijay HK, Anitha S. Synthesis and evaluation of $p$ coumaric acid amides as antioxidants. . Inter $\mathrm{J}$ Pharm Pharmaceut Sci 2011:3(3):57-62.

28. Ambersing P, Rajput PG, Rambhau PG. N-acylation in non-aqueous and aqueous medium (method of amide synthesis in non-peptide compounds). Der Pharma Chemica 2011;3(3):409-21.

29. Shadpour M, Majid K. Preparation and characterization of novel optically active poly (amide-esterimide) based on bis ( $p$-amino bezoic acid)- $N$-trimellitylimido- $S$-valine via direct Poly-esterification. Iranian J Polymer 2006;15 (4):30715.

30. Tale RH, Rodge AH, Keche AB, et al. Synthesis and antibacterial, antifungal activity of novel 1,2,4oxadiazole. J Chem Pharm Res 2011;3(2):496-505.

31. Ariella Z, Vijaya M, Samuel R. Mechanism of the anticoagulant 
effect of warfarin as evaluated in rabbits by selective depression of individual pro-coagulant vitamin $\mathrm{K}$-dependent clotting factors. J Clin Invest 1993;92:2131-40.

32. Marc M. Acute traumatic coagulopathy: incidence, risk stratification and therapeutic options. World J Emerg Med 2010;1(1):1221.

33. Anton B, Martha H, Evelina W, et al. Influence of blood collection systems on the prothrombin time and international sensitivity index determined with human and rabbit thromboplastin reagents. Am J Clin Pathol 2007;127:724-9.
34. Rao LV, Okorodu AO, Petersen JR, et al. Stability of prothrombin time and activated partial prothrombin time tests under different storage conditions. Clin Chim Acta 2000;300:13-21.

35. Adak M, Shivapuri JN. Enzymatic and non-enzymatic liver function test. Research Journal of Pharmaceutical, Biol Chem Sci 2010;1(4):593-605.

36.Lavhekar SS, Bhopale AK, Lohade AA, et al. Determination of microsomal CYP2A6 activity by high performance liquid chromatography. Indian J Pharma Sci 2007;69(3):448-51. 